\title{
A test of cognitive mediation in a 12-month physical activity workplace intervention: does it explain behaviour change in women?
}

\author{
Ronald C Plotnikoff*1,2,3,4, Michael A Pickering2,3, Ryan E Rhodes5, Kerry S Courneya² and John C Spence 2
}

\begin{abstract}
Background: Attempts to demonstrate the efficacy of interventions aimed at increasing physical activity (PA) have been mixed. Further, studies are seldom designed in a manner that facilitates the understanding of how or why a treatment is effective or ineffective and PA intervention designs should be guided by a heavier reliance upon behavioral theory. The use of a mediating variable framework offers a systematic methodological approach to testing the role of theory, and could also identify the effectiveness of specific intervention components. The primary purpose of this paper was to test the mediating role that cognitive constructs may have played in regards to the positive effect that a workplace behavioral intervention had on leisure-time PA for women. A subsidiary purpose was to examine the cross-sectional relationships of these cognitive constructs with PA behavior.
\end{abstract}

Methods: The Physical Activity Workplace Study was a randomized controlled trial which compared the effects of stage-matched and standard print materials upon self-reported leisure-time PA, within a workplace sample at 6 and 12-months. In this secondary analysis we examined the mediation effects of 14 psychosocial constructs across 3 major social-cognitive theories which were operationalized for the intervention materials and measured at baseline, 6 and 12-months. We examined change in PA and change in the psychological constructs employing a mediation strategy proposed by Baron and Kenny for: (1) the first 6-months (i.e., initial change), (2) the second 6-months (i.e., delayed change), and (3) the entire 12-months (overall change) of the study on 323 women ( $n=213$ control/standard materials group; $\mathrm{n}=110$ stage-matched materials group).

Results: Of the 14 constructs and 42 tests (including initial, delayed and overall change) two positive results were identified (i.e., overall change in pros, initial change in experiential powerful intervention approaches processes), with very small effect sizes. However, these mediating results were eliminated after adjusting for the multiple statistical tests.

Conclusions: The intervention did not change these mediators in any substantive way, and show a similar pattern to prior research where interventions generally do not result in a change in mediation of behavior change. It is important to report mediation results in randomized controlled trials whether the findings are null or positive. Future studies may wish to focus on more detailed dose-response issues between mediators and behavior, the inclusion of moderators that could affect individual change, or different mediator constructs at higher levels of measurement specificity. Continued work on innovative and more powerful PA intervention approaches are needed.

\section{Background}

In light of the compelling evidence supporting positive effects of regular physical activity (PA) [1], a significant

\footnotetext{
* Correspondence: ron.plotnikoff@newcastle.edu.au

1 School of Education, University of Newcastle, Callaghan, NSW, Australia Full list of author information is available at the end of the article
}

proportion of our population remain sedentary [2]. It is not surprising, therefore, that health researchers have turned attention to identifying and validating methods of increasing PA levels of individuals to improve the health of our population [3]. To date, attempts to demonstrate the efficacy of interventions aimed at increasing PA have 
been mixed. In a systematic review of 23 physical activity intervention studies, Baranowski and colleagues [4] reported that many published intervention studies had little or no impact on PA behavior. The authors also concluded that PA interventions often demonstrated effects only for a subset of targeted outcome measures or only for some subgroups at some times, but not other time points. A more recent comprehensive meta-analysis across all contexts of physical activity interventions revealed an overall small effect size (i.e., $d=.31$ ) [5]. In a meta-analysis specifically focused on workplace PA interventions, Dishman et al. [6] reported an overall small effect size $(r=0.11)$ across 26 studies.

According to Baranowski et al. [4], studies are seldom designed in a manner that facilitates the understanding of how or why a treatment is effective, and these authors recommend that PA intervention designs be guided by a heavier reliance upon behavioral theory. Other researchers $[7,8]$ have made similar recommendations.

In addition to suggesting a stronger theoretical foundation, Baranowski et al. [4] also point out that the use of a mediating variable framework offers a systematic methodological approach to testing the role of theory, and could also identify the effectiveness of specific intervention components. Other researchers have made calls for an increased emphasis and utilization of mediation designs in physical activity research [9-11]. The rationale underlying this emphasis is that theory-based intervention research postulates a particular treatment will increase PA by influencing specific constructs that relate to behavior change [8]. Thus, a mediating variable framework provides a basis for examining both the overall efficacy of the intervention, and its proposed mechanism of operation [3,12].

Experimental designs that assess the relationship between change in cognitive mediators and change in behavior [4] are further enhanced when more than two assessments are included so that the time precedence requirement of causal inference can also be established $[3,8]$. It is important to assess mediators alongside intervention outcomes to obtain a better understanding of intervention efforts. Our current understanding of theories is predominantly based on correlational designs [1315 ] and more studies need to be conducted to examine the internal validity of these theories.

The Physical Activity Workplace Study (PAWS) [16] incorporated a randomized controlled trial design to compare the effects of introducing stage-matched and standard print materials upon self-reported leisure-time PA, within a workplace sample. In addition to assessing self-reported PA prior to the intervention, and at two follow-up time points (i.e., at six and 12 months), PAWS participants also reported levels of 14 cognitive constructs at all three assessments. The selected cognitions were based on social-cognitive theories namely, Transtheoretical Model [17], Theory of Planned Behavior [18], Protection Motivation Theory [19] and Social Cognitive Theory [20] which are frequently employed in physical activity literature and were operationalized in an integrated theoretical manner for promoting behavior stage of change.

Plotnikoff et al. [16] reported a significant positive effect of the stage-matched intervention upon leisure time PA for females but not for males. However, the original PAWS report did not explore the effect of the intervention on the cognitive constructs, nor did it examine the relationships between the cognitions and leisure time PA.

Therefore, the primary purpose of these follow-up analyses was to investigate the potential mediating role that the cognitive constructs may have played in regards to the positive effect that the PAWS intervention had on leisure-time PA for women. A secondary purpose was to confirm that the theoretical constructs examined as potential mediators of PA were empirically reasonable choices, regardless of observed intervention effects. Specifically, to meet our first purpose we: (a) identified what particular cognitions changed in women, in response to the intervention, (b) determined what cognitive changes were related to PA change, and (c) evaluated whether inclusion of cognitive change within a mediation framework significantly attenuated the observed direct effect of the intervention on PA. To address our second purpose we examined bivariate and partial correlations of each cognition with PA behavior.

\section{Methods}

\section{Design}

A detailed description of the methods used in the PAWS study has been reported elsewhere [16,21]. In brief, the study was conducted to compare the efficacy of (1) a stage-matched intervention (based on print materials matched for PA stage of readiness), with (2) a standard print-based intervention [the Canadian Physical Activity Guide (CPAG)] [22], and (3) a control group. The primary outcome variable was self-reported leisure time PA. Participants were recruited from three large Canadian worksites via flyers, posters and e-mail notification. Each worksite was further subdivided into geographicallybased sub-sites, which were then randomly assigned to one of the three study arms. A University Research Ethics Committee approved all study procedures.

In the original PAWS report the intervention was effective for females in the stage-matched treatment group, who reported greater increases in PA than women in either the standard treatment group (i.e., those who received the CPAG) or the control group. Women participants in the standard treatment and control groups did 
not differ in PA change [16]. According to Cohen's guidelines, there was more than adequate power $(>.80$; alpha < .05 ) with the group N's to detect a medium effect size (i.e., a mean difference of 0.5 of a standard deviation) between the three study groups (as well as between the combined standard and control group versus the stagematched group) in the subsample of women on PA behavior over the course of the study [23]. Subsequent analyses further revealed almost no differences between the standard versus control groups on cognitive change over the duration of the study. Of the 14 social cognitive variables examined in the study, only one construct (i.e., 'perceived behavioral control') changed significantly between the groups over time $(\mathrm{p}=.03)$; the magnitude of the difference was small (approx .20 on the 5-point scale). In the current analyses we combined women in the standard treatment group with the control group women, and compared this new group against women who received the stage-matched print materials.

\section{Participants}

Participants were employees from three large organizations in the province of Alberta, Canada [16]. Though 897 participants were recruited in the original study, 507 (56.5\%) completed the questionnaire at all three time periods. The current analyses are restricted to women who completed the questionnaires at all three assessments, and who included sufficient information for change in PA scores to be computed ( $\mathrm{n}=326$ of 661 females, 49.3\%). (For consistency, it was important to employ the same $\mathrm{N}$ of women as reported in the primary paper [16] for our mediation analyses; therefore we did not impute the last observation carried forward technique for those missing the 6 and 12-month assessments.) Of these, three women reported changes in MET-minutes scores from Time 1 to Time 3 of greater than 5000 MET-minutes, which was substantially more than three standard deviations from the mean MET-minutes change score. Thus, these three cases were considered outliers, and were removed from subsequent analyses. The women remaining in the sample $(\mathrm{n}=324)$ exhibited a mean age of 42.6 years $(\mathrm{SD}=8.8)$, and were highly educated $(82.0 \%$ reported having at least a college degree). Approximately three-quarters $(\mathrm{n}=244)$ of the remaining sample reported being in a committed relationship (i.e., either married or common law). Two-thirds $(\mathrm{n}=217)$ reported working full time, $31.5 \%(\mathrm{n}=102)$ worked part-time, and less than $1 \%$ of the respondents were volunteers $(n=3)$. Two women in the sample did not report their employment status. For this study analyses, the combined control and standard materials group consisted of 213 women, while the stage-matched group comprised 110 women; there were no statistical differ- ences between the groups on the above-mentioned demographic characteristics.

\section{Measures}

Questionnaires that included demographic information, self-reported leisure time PA, and several psychosocial constructs, were collected at three times: baseline, sixmonths, and 12-months.

\section{demographic characteristics}

Age, gender, marital status, education level, gross family income, employment status, height and weight were collected as part of the baseline assessment.

\section{physical activity}

Respondents reported frequency, duration, and level of intensity (i.e., light, moderate or strenuous) of weekly PA sessions, based on a modified version [16] of the Godin Leisure-Time Exercise Questionnaire (GLTEQ) [24]. Frequency and duration of moderate and strenuous sessions were multiplied together, then weighted by estimates of metabolic equivalents (i.e., 4.0 MET for moderate activity and 7.5 MET for strenuous activity) [25]. MET.minutes scores for each session were totalled, providing an estimate of total weekly PA. Light activity was not included in the PA calculations.

\section{psychological constructs}

A total of 14 psychosocial constructs from the Theory of Planned Behavior [18], Transtheoretical Model [17], Protection Motivation Theory [19], and Social Cognitive Theory $[20,26]$, were considered as potential mediators of the intervention effect upon self-reported PA (see Plotnikoff et al. [16] for details of our rationale). Table 1 displays (a) an example item from each scale, (b) response scale anchors and number of items (c) instrument development source, and (d) reliability coefficients for each assessment in this study. Constructs scores were computed as the mean value of responses to each scale's individual items.

\section{Statistical Analyses}

Our analytical approach consisted of product of coefficients tests of mediation [27] and was guided by the previously reported findings of the PAWS study [16]. To explore the potential mediation processes, we employed a mediation strategy proposed by Baron and Kenny [28]. We first confirmed the overall stage-matched intervention effect for women (i.e., path 'c' in Figure 1) by regressing self-reported PA change upon a dummy-coded indicator of group membership (i.e., stage-matched materials vs. CPAG print materials or control group). Next, we examined the effect of the stage-matched intervention on the various psychological constructs (i.e., path 'a' in Figure 1) by separately regressing change in each of the cognitions upon intervention group membership. If the 
Table 1: Example items from each psychological construct scale, number of items and response scale, instrument development source(s), and reliability coefficients computed at each assessment point in this study.

\begin{tabular}{|c|c|c|c|c|}
\hline $\begin{array}{l}\text { Psychological } \\
\text { construct }\end{array}$ & Sample item & $\begin{array}{c}\text { Response scale } \\
\text { (number of items) }\end{array}$ & $\begin{array}{l}\text { Construct source(s) } \\
\text { [reference number] }\end{array}$ & $\begin{array}{l}\text { aT1 } \\
\text { aT2 } \\
\text { aT3 }\end{array}$ \\
\hline self-efficacy & $\begin{array}{l}\text { In the next six months, I } \\
\text { am confident that I can } \\
\text { participate in regular } \\
\text { physical activity: } \\
\text { When I have to do it by } \\
\text { myself. }\end{array}$ & $\begin{array}{l}\text { "Not confident at all" to } \\
\text { "Extremely confident" } \\
\text { (9 items) }\end{array}$ & {$[43,44]$} & $\begin{array}{l}.93 \\
.93 \\
.94\end{array}$ \\
\hline $\begin{array}{l}\text { decisional balance } \\
\text { pros }\end{array}$ & $\begin{array}{l}\text { Over the next } 6 \text { months: } \\
\text { Physical activity would } \\
\text { help reduce tension or } \\
\text { manage stress. }\end{array}$ & $\begin{array}{l}\text { "Not at all" to "Very } \\
\text { much" } \\
\text { (5 items) }\end{array}$ & {$[43,44]$} & $\begin{array}{l}.85 \\
.83 \\
.85\end{array}$ \\
\hline $\begin{array}{l}\text { decisional balance } \\
\text { cons }\end{array}$ & $\begin{array}{l}\text { Over the next } 6 \text { months: } \\
\text { Physical activity would } \\
\text { take too much time. }\end{array}$ & $\begin{array}{l}\text { "Not at all" to "Very } \\
\text { much" } \\
\text { ( } 6 \text { items) }\end{array}$ & {$[43,44]$} & $\begin{array}{l}.77 \\
.75 \\
.78\end{array}$ \\
\hline behavioral processes & $\begin{array}{l}\text { How often in the past } \\
\text { month: } \\
\text { Did you set physical } \\
\text { activity goals for } \\
\text { yourself that you could } \\
\text { reach? }\end{array}$ & $\begin{array}{l}\text { "Never" to "Very often" } \\
\text { (9 items) }\end{array}$ & {$[44]$} & $\begin{array}{l}.86 \\
.84 \\
.87\end{array}$ \\
\hline experiential processes & $\begin{array}{l}\text { How often in the past } \\
\text { month: } \\
\text { Did warnings about } \\
\text { health problems cause } \\
\text { concern? }\end{array}$ & $\begin{array}{l}\text { "Never" to "Very often" } \\
\text { (10 items) }\end{array}$ & {$[44]$} & $\begin{array}{l}.81 \\
.80 \\
.82\end{array}$ \\
\hline severity & $\begin{array}{l}\text { I feel: } \\
\text { For me, being } \\
\text { physically inactive } \\
\text { would be a very bad } \\
\text { thing. }\end{array}$ & $\begin{array}{l}\text { "Definitely not" to } \\
\text { "Definitely yes" } \\
\text { ( } 3 \text { items) }\end{array}$ & {$[45,46]$} & $\begin{array}{l}.61 \\
.60 \\
.81\end{array}$ \\
\hline vulnerability & $\begin{array}{l}\text { I feel: } \\
\text { If I don't get enough } \\
\text { physically activity, I } \\
\text { would be at risk for } \\
\text { serious health } \\
\text { problems. }\end{array}$ & $\begin{array}{l}\text { "Definitely not" to } \\
\text { "Definitely yes" } \\
\text { ( } 3 \text { items) }\end{array}$ & {$[45,46]$} & $\begin{array}{l}.84 \\
.92 \\
.91\end{array}$ \\
\hline fear & $\begin{array}{l}\text { I feel: } \\
\text { Not getting enough } \\
\text { physical activity would } \\
\text { frighten me because of } \\
\text { the possibility of } \\
\text { developing serious } \\
\text { health problems. }\end{array}$ & $\begin{array}{l}\text { "Definitely not" to } \\
\text { "Definitely yes" } \\
\text { ( } 3 \text { items) }\end{array}$ & {$[45,46]$} & $\begin{array}{l}.93 \\
.94 \\
.95\end{array}$ \\
\hline response efficacy & $\begin{array}{l}\text { I feel: } \\
\text { For me, physical } \\
\text { activity will keep me } \\
\text { healthy. }\end{array}$ & $\begin{array}{l}\text { "Definitely not" to } \\
\text { "Definitely yes" } \\
\text { ( } 3 \text { items) }\end{array}$ & {$[45,46]$} & $\begin{array}{l}.83 \\
.78 \\
.91\end{array}$ \\
\hline attitude & $\begin{array}{l}\text { For me regular physical } \\
\text { activity over the next } 6 \\
\text { months will be: } \\
\text { "Quite Useful" to } \\
\text { "Quite Useless" }\end{array}$ & $\begin{array}{l}\text { Response scale } \\
\text { differed for each item } \\
\text { (i.e., enjoyable, useful, } \\
\text { wise, interesting, } \\
\text { relaxing, beneficial) (6 } \\
\text { items) }\end{array}$ & {$[47,48]$} & $\begin{array}{l}.78 \\
.82 \\
.80\end{array}$ \\
\hline
\end{tabular}


Table 1: Example items from each psychological construct scale, number of items and response scale, instrument development source(s), and reliability coefficients computed at each assessment point in this study. (Continued)

\begin{tabular}{|c|c|c|c|c|}
\hline injunctive norms & $\begin{array}{l}\text { Over the next } 6 \text { months: } \\
\text { Most people in my } \\
\text { social network want } \\
\text { me to do regular } \\
\text { physical activity. }\end{array}$ & $\begin{array}{l}\text { "Strongly disagree" to } \\
\text { "Strongly agree" } \\
\text { (4 items) }\end{array}$ & {$[47,48]$} & $\begin{array}{l}.67 \\
.73 \\
.73\end{array}$ \\
\hline descriptive norms & $\begin{array}{l}\text { Over the next } 6 \text { months: } \\
\text { Most of my family } \\
\text { members will } \\
\text { participate in regular } \\
\text { physical activity. }\end{array}$ & $\begin{array}{l}\text { "Strongly disagree" to } \\
\text { "Strongly agree" } \\
\text { (4 items) }\end{array}$ & {$[47,48]$} & $\begin{array}{l}.55 \\
.61 \\
.63\end{array}$ \\
\hline social support & $\begin{array}{l}\text { Over the next } 6 \text { months: } \\
\text { People in my social } \\
\text { network are likely to } \\
\text { help me participate in } \\
\text { regular physical } \\
\text { activity. }\end{array}$ & $\begin{array}{l}\text { "Strongly disagree" to } \\
\text { "Strongly agree" } \\
\text { (3 items) }\end{array}$ & {$[47,48]$} & $\begin{array}{l}.76 \\
.73 \\
.73\end{array}$ \\
\hline $\begin{array}{l}\text { perceived behavioral } \\
\text { control }\end{array}$ & $\begin{array}{l}\text { Over the next } 6 \text { months: } \\
\text { If I were really } \\
\text { motivated } \\
\text { participating in regular } \\
\text { physical activity would } \\
\text { be easy. }\end{array}$ & $\begin{array}{l}\text { Response scale } \\
\text { differed for each item } \\
\text { ( } 4 \text { items) }\end{array}$ & [47] & $\begin{array}{l}.57 \\
.60 \\
.60\end{array}$ \\
\hline
\end{tabular}

regression coefficients for both paths 'a' and 'c' were significant, we then regressed the change in PA upon the dummy-coded intervention variable and the change in the potential mediator simultaneously. This third step determined: (a) if change in the potential mediating psychological construct had a significant relationship with the change in PA, after controlling for the effect the intervention had on both (i.e., path ' $b$ ' in Figure 1), and (b) if the direct effect of the intervention upon PA change was attenuated (as compared to the direct effect when the mediator was not included in the model), as is required to infer that at least partial mediation was plausible [29]. Testing the statistical significance of the indirect effect through paths ' $a$ ' and ' $b$ ' is equivalent to that of the attenuation of path 'c' [29]. Statistical significance of the indirect effect was based upon the Sobel test statistic [30], which has been shown to be stable for single mediator models

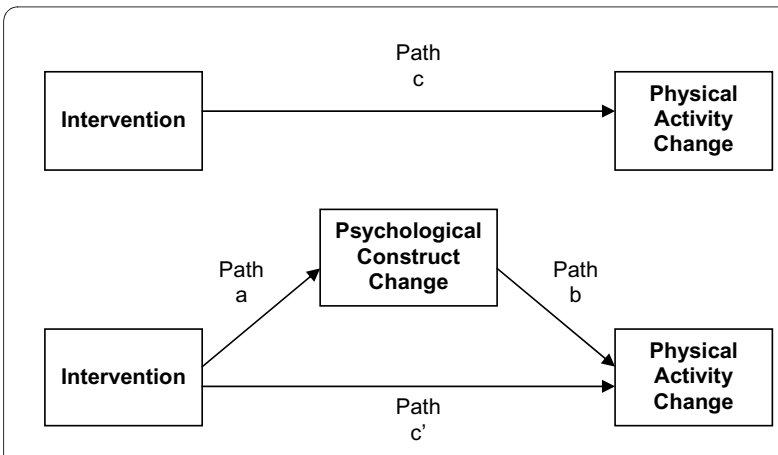

Figure 1 Overview of mediation process and analysis procedure. with sample sizes greater than $\mathrm{N}=50$ [31]. Based on the sample sizes of our two study groups, we had power at the 0.8 level to detect medium effect sizes for any potential mediation effects of the psychosocial constructs [32].

Although mediation analysis typically stops if either path 'c' or path 'a' is not statistically significant, in order to address our second study aim we proceeded to calculate bivariate and partial correlations (controlling for the intervention effect), between change in each of the psychological constructs and change in PA. This served as an empirical post-hoc confirmation of the appropriateness of the theory-based cognitions that were chosen as potential mediators. In other words, did changes in these cognitions relate to change in physical activity, as theory would suggest, irrespective of the effects or non-effects of the intervention.

Finally, change in PA across the entire 12-month intervention was presented in the original PAWS report [16]. However, specific examination of the pattern of change within the 12 months was not reported. In these followup analyses we examined change in PA and change in the psychological constructs for: (1) the first six months (i.e., initial change), (2) the second six months (i.e., delayed change), and (3) the entire 12 months (overall change) of the study. Throughout this report, references to initial change of PA and cognitions at six months (Time 2) and overall change at 12 months (Time 3 ) refer to residual change; post-test values were regressed onto their baseline values to create residualized change scores. 


\section{Results}

\section{Preliminary Analyses}

Prior to performing mediation analyses all 14 cognitive constructs and leisure time PA levels were compared between study participants who provided sufficient data for these analyses (i.e., completed all three assessments and provided PA data) and those who did not (i.e., either did not complete all three assessments or did not provide sufficient data to calculate change in PA levels). Independent t-tests indicated that no significant differences on PA levels, or on 13 of the 14 psychological constructs (i.e., all p-values $>.10$ ). For the one significant construct (i.e., severity), participants who were not included in these analyses $(n=333)$ reported slightly lower levels $(M=$ $4.62, \mathrm{SD}=0.60)$ than did participants who were $[(\mathrm{n}=325$; $\mathrm{M}=4.73, \mathrm{SD}=0.46), \mathrm{t}(656)=-2.60, \mathrm{p}=.01]$, however the magnitude of this difference was small. Thus, although the current mediation analyses are based on approximately one-half of the participants originally recruited, there were no substantive differences in baseline characteristics between those who provided sufficient data for these analyses and those who either dropped out of the study or provided insufficient data, in regards to leisure time physical activity and the psychological constructs under consideration. Moreover, there were no drop-out differences between the study groups.

\section{Path c: Direct Intervention Effect on Changes in Physical Activity}

The top panel of Table 2 indicates that the dummy-coded intervention group variable contributed significantly to prediction of both delayed and overall change in leisure time PA. Treatment group membership did not predict change in PA during the first six months of the study. Specifically, after controlling for individual activity levels reported at the beginning of each time period, women in the stage-matched group reported significantly higher weekly leisure time PA, by approximately 320 and 270 MET-minutes, during the second six months and over the entire 12 months respectively, as compared to women in the combined CPAG and control group. Group membership accounted for $2.6 \%$ of the variance in delayed PA change and $2.1 \%$ in overall PA change.

\section{Path a: Intervention Effect on Changes in Psychological Constructs}

Tables 2 and 3 display residual change score means and associated unstandardized regression coefficients, p-values, effect-sizes and power for the intervention effect upon all 14 psychological construct change scores, including initial, delayed, and overall change. Out of 42 models exploring the possible mediating role of psychological constructs, only two indicated that the stagematched intervention contributed significantly toward predicting changes in the cognitions. On average, overall change in pros, and initial change in experiential processes, both increased approximately 0.15 units more (on a 5 point scale) for the stage-matched intervention group than for the CPAG plus control group. The intervention accounted for $1.3 \%$ and $2.0 \%$ of the variance in overall change in pros and initial change in experiential processes, respectively. Instead of adjusting p-values for the number of tests, we have reported exact p-values, effect sizes, and power estimates for all analyses in Tables 2 and 3 , so that readers may evaluate significance of results for themselves. In light of effect size and power considerations, our mediation analyses were guided by uncorrected p-criteria of .05 as representing individual effects unlikely to have been observed in our samples, if in fact, no such effects would be evident in populations with similar characteristics.

\section{Path b: Effect of Cognitive Changes on Changes in Physical Activity}

The pros construct showed the only significant overall change in response to the stage-matched intervention. Therefore, it was considered as a potential mediator only for overall change in leisure time PA. The path $b$ mediation coefficient showed a significant relationship between the overall change in pros and the overall change in leisure time PA. Specifically, for every one unit of overall change in pros, weekly leisure time PA increased by 162.0 METs, after controlling for initial level of pros and the effect of the intervention.

The experiential process construct showed significant initial change, and was therefore considered a potential mediator for both the delayed and overall change in leisure time PA. However, neither the path $b$ coefficient from initial change in experiential processes to delayed change in physical activity, nor the path $b$ coefficient from initial change in experiential processes to overall change in $\mathrm{PA}$, was statistically significant $\left(\mathrm{B}_{\text {delayed } \mathrm{PA}}=\right.$ $58.3, \mathrm{p}=.584 ; \mathrm{B}_{\text {overall } \mathrm{PA}}=62.4, \mathrm{p}=.532$ ).

\section{Mediation Effects (Attenuation of Path c)}

Evaluating the significance of the magnitude of a mediating effect (attenuation of path c) is typically pursued only if both path $a$, and path $b$ are significant. Based on our criteria, only the potential indirect effect of the stagematched intervention upon overall change in leisure time PA, through the overall change in pros, exhibited significance of both paths, and thus, was the only mediating effect examined for statistical significance.

\section{mediation via change in pros}

The change in $\mathrm{R}^{2}$ values when the intervention was added as a second predictor of PA change (in addition to change in pros) was .017. This $\mathrm{R}^{2}$ change value was slightly smaller in magnitude than the $\mathrm{R}^{2}$ value of .021 that was 
Table 2: Group means (i.e., stage-matched vs. CPAG + control), unstandardized regression coefficients, p-values, effect-size, and power for self-reported physical activity and eight of 14 potential mediating psychological constructs.

\begin{tabular}{|c|c|c|c|c|c|c|}
\hline \multicolumn{7}{|c|}{ Group Means } \\
\hline & $\begin{array}{c}\text { Stage- } \\
\text { matched }\end{array}$ & $\begin{array}{l}\text { Control + } \\
\text { CPAG }\end{array}$ & B & $\mathbf{p}$ & $\mathbf{R 2}$ & power \\
\hline \multicolumn{7}{|l|}{$\begin{array}{l}\text { Physical } \\
\text { activity }\end{array}$} \\
\hline Initial Change & -76.510 & -15.640 & -60.867 & 0.564 & 0.001 & 0.089 \\
\hline $\begin{array}{l}\text { Delayed } \\
\text { Change }\end{array}$ & 104.121 & -214.392 & 318.513 & 0.004 & 0.026 & 0.818 \\
\hline $\begin{array}{l}\text { Overall } \\
\text { Change }\end{array}$ & 70.496 & -198.624 & 269.120 & 0.009 & 0.021 & 0.746 \\
\hline \multicolumn{7}{|l|}{ Self-efficacy } \\
\hline Initial Change & 0.068 & -0.015 & 0.083 & 0.207 & 0.005 & 0.243 \\
\hline $\begin{array}{c}\text { Delayed } \\
\text { Change }\end{array}$ & 0.036 & 0.035 & 0.002 & 0.979 & 0.000 & 0.050 \\
\hline $\begin{array}{l}\text { Overall } \\
\text { Change }\end{array}$ & 0.071 & 0.011 & 0.060 & 0.392 & 0.002 & 0.137 \\
\hline \multicolumn{7}{|l|}{ Pros } \\
\hline Initial Change & 0.093 & 0.001 & 0.092 & 0.216 & 0.005 & 0.235 \\
\hline $\begin{array}{c}\text { Delayed } \\
\text { Change }\end{array}$ & 0.075 & 0.005 & 0.071 & 0.305 & 0.003 & 0.176 \\
\hline $\begin{array}{l}\text { Overall } \\
\text { Change }\end{array}$ & 0.121 & -0.023 & 0.145 & 0.041 & 0.013 & 0.533 \\
\hline \multicolumn{7}{|l|}{ Cons } \\
\hline Initial Change & 0.014 & 0.001 & 0.013 & 0.827 & 0.000 & 0.055 \\
\hline $\begin{array}{l}\text { Delayed } \\
\text { Change }\end{array}$ & -0.024 & -0.011 & -0.013 & 0.823 & 0.000 & 0.056 \\
\hline $\begin{array}{l}\text { Overall } \\
\text { Change }\end{array}$ & -0.014 & 0.008 & -0.022 & 0.728 & 0.000 & 0.064 \\
\hline \multicolumn{7}{|l|}{$\begin{array}{l}\text { Experiential } \\
\text { processes }\end{array}$} \\
\hline Initial Change & 0.125 & -0.023 & 0.148 & 0.011 & 0.020 & 0.726 \\
\hline $\begin{array}{l}\text { Delayed } \\
\text { Change }\end{array}$ & -0.022 & 0.030 & -0.052 & 0.380 & 0.002 & 0.142 \\
\hline $\begin{array}{l}\text { Overall } \\
\text { Change }\end{array}$ & 0.061 & 0.006 & 0.055 & 0.390 & 0.002 & 0.138 \\
\hline \multicolumn{7}{|l|}{$\begin{array}{l}\text { Behavioral } \\
\text { processes }\end{array}$} \\
\hline Initial Change & 0.036 & 0.037 & -0.001 & 0.987 & 0.000 & 0.050 \\
\hline $\begin{array}{l}\text { Delayed } \\
\text { Change }\end{array}$ & 0.076 & -0.002 & 0.078 & 0.264 & 0.004 & 0.201 \\
\hline $\begin{array}{l}\text { Overall } \\
\text { Change }\end{array}$ & 0.033 & -0.015 & 0.048 & 0.491 & 0.001 & 0.106 \\
\hline \multicolumn{7}{|l|}{ Severity } \\
\hline Initial Change & 0.037 & -0.012 & 0.049 & 0.356 & 0.003 & 0.152 \\
\hline $\begin{array}{l}\text { Delayed } \\
\text { Change }\end{array}$ & -0.028 & 0.000 & -0.028 & 0.679 & 0.001 & 0.070 \\
\hline
\end{tabular}


Table 2: Group means (i.e., stage-matched vs. CPAG + control), unstandardized regression coefficients, p-values, effect-size, and power for self-reported physical activity and eight of 14 potential mediating psychological constructs. (Continued)

\begin{tabular}{|c|c|c|c|c|c|c|}
\hline $\begin{array}{c}\text { Overall } \\
\text { Change }\end{array}$ & -0.027 & -0.032 & 0.005 & 0.942 & 0.000 & 0.051 \\
\hline \multicolumn{7}{|l|}{ Vulnerability } \\
\hline Initial Change & 0.049 & -0.081 & 0.131 & 0.152 & 0.006 & 0.298 \\
\hline $\begin{array}{l}\text { Delayed } \\
\text { Change }\end{array}$ & -0.003 & 0.009 & -0.012 & 0.894 & 0.000 & 0.052 \\
\hline $\begin{array}{l}\text { Overall } \\
\text { Change }\end{array}$ & 0.009 & -0.029 & 0.037 & 0.664 & 0.001 & 0.072 \\
\hline \multicolumn{7}{|l|}{ Fear } \\
\hline Initial Change & 0.001 & -0.011 & 0.012 & 0.910 & 0.000 & 0.051 \\
\hline $\begin{array}{l}\text { Delayed } \\
\text { Change }\end{array}$ & 0.064 & -0.047 & 0.111 & 0.213 & 0.005 & 0.238 \\
\hline $\begin{array}{l}\text { Overall } \\
\text { Change }\end{array}$ & 0.052 & -0.056 & 0.108 & 0.235 & 0.004 & 0.220 \\
\hline
\end{tabular}

Bolded values $=p<.05$

observed when the stage-matched intervention was the only predictor of change in leisure time PA.

The magnitude of this indirect effect was 23.50 METminutes (i.e., the mediating effect accounted for a 23.5 MET-minutes greater change in PA for the intervention group than for the control group), and the associated Sobel $\mathrm{z}=1.430$ was not statistically significant $(\mathrm{p}=.153)$. Thus, although the amount of unique variance shared between the intervention and PA was less when the change in pros was also included as a predictor than when the intervention predicted PA alone, the mediating effect was not large enough to consider change in perceived benefits of PA (pros) as a significant mediator of the intervention effect upon the self-reported changes in leisure time PA.

\section{Bivariate and partial correlations of cognitions with physical activity change}

Tables 4 and 5 presents the bivariate and partial correlations of the cognitive changes with PA change (regardless of intervention effects on cognitions).

\section{Discussion}

The primary purpose of this study was to examine the potential mediators of behavior change in a worksite-distributed PA intervention [16]. Potential mediators included constructs of the Theory of Planned Behavior, Protection Motivation Theory, the Transtheoretical Model, and Social Cognitive Theory allowing for a broad assortment of social-cognitive constructs. The results suggest a general failure of these constructs to account for mediation, and several potential reasons for this null effect are discussed below. We believe the results of this study will inform future research efforts.
Of the 14 constructs and 42 tests (including initial change, delayed change, and overall change) only two positive results were identified (i.e., overall change in pros, initial change in experiential processes), and these were of very small effect size [23]. Adjusting the alpha to account for the multiple tests, eliminate any mediation effect in this study.

Thus, it is clear that the intervention did not change these mediators in any substantive way. Low fidelity observed in our current interventions has also been found among many other trials (see Lewis et al. [8], Lubans et al, [33], and Rhodes and Pfaeffi [34] for reviews). In a recent study [35] somewhat similar to ours also reported that a lifestyle physical activity intervention in women effectively increased physical activity, but none of the proposed psychosocial constructs showed a mediating effect. In a recent review of 28 primary prevention PA trials, Rhodes and Pfaeffli [34] found that over half of the trials failed to change the proposed mediators of the intervention.

Clearly, continued innovation to increase the power of interventions is needed to bring about change in socialcognitive variables. This problem poses less of a challenge to current theories as it does to interventions; nevertheless, it does suggest that social-cognitive constructs may be difficult to change following interventions. Interestingly, in our study, several of the changes in social-cognitive constructs were related to subsequent changes in PA independent of the intervention arm. Thus, there was some evidence of validity for these mediators despite the intervention's failure to change these constructs. However, there are practical limitations to changing these constructs that also need consideration. For example, many of the constructs demonstrated very high mean val- 
Table 3: Group means (i.e., stage-matched vs. CPAG + control), unstandardized regression coefficients, p-values, effectsize, and power for the remaining six of 14 potential mediating psychological constructs.

\begin{tabular}{|c|c|c|c|c|c|c|}
\hline \multicolumn{7}{|c|}{ Group Means } \\
\hline & $\begin{array}{c}\text { Stage- } \\
\text { matched }\end{array}$ & $\begin{array}{l}\text { Control + } \\
\text { CPAG }\end{array}$ & B & $\mathbf{p}$ & $\mathbf{R 2}$ & power \\
\hline \multicolumn{7}{|l|}{$\begin{array}{l}\text { Response } \\
\text { efficacy }\end{array}$} \\
\hline $\begin{array}{r}\text { Initial } \\
\text { Change }\end{array}$ & 0.056 & -0.007 & 0.063 & 0.187 & 0.005 & 0.261 \\
\hline $\begin{array}{l}\text { Delayed } \\
\text { Change }\end{array}$ & 0.046 & -0.011 & 0.057 & 0.382 & 0.002 & 0.141 \\
\hline $\begin{array}{l}\text { Overall } \\
\text { Change }\end{array}$ & 0.073 & -0.019 & 0.092 & 0.160 & 0.006 & 0.290 \\
\hline \multicolumn{7}{|l|}{ Attitude } \\
\hline $\begin{array}{r}\text { Initial } \\
\text { Change }\end{array}$ & -0.090 & -0.003 & -0.087 & 0.079 & 0.010 & 0.420 \\
\hline $\begin{array}{l}\text { Delayed } \\
\text { Change }\end{array}$ & -0.016 & 0.008 & -0.025 & 0.567 & 0.001 & 0.088 \\
\hline $\begin{array}{l}\text { Overall } \\
\text { Change }\end{array}$ & -0.055 & 0.010 & -0.066 & 0.187 & 0.005 & 0.261 \\
\hline \multicolumn{7}{|l|}{$\begin{array}{l}\text { Injunctive } \\
\text { norms }\end{array}$} \\
\hline $\begin{array}{r}\text { Initial } \\
\text { Change }\end{array}$ & 0.080 & 0.054 & 0.026 & 0.640 & 0.001 & 0.075 \\
\hline $\begin{array}{l}\text { Delayed } \\
\text { Change }\end{array}$ & 0.024 & -0.018 & 0.041 & 0.469 & 0.002 & 0.112 \\
\hline $\begin{array}{l}\text { Overall } \\
\text { Change }\end{array}$ & 0.062 & 0.001 & 0.061 & 0.288 & 0.004 & 0.186 \\
\hline \multicolumn{7}{|l|}{$\begin{array}{l}\text { Descriptive } \\
\text { norms }\end{array}$} \\
\hline $\begin{array}{r}\text { Initial } \\
\text { Change }\end{array}$ & 0.056 & 0.009 & 0.046 & 0.507 & 0.001 & 0.101 \\
\hline $\begin{array}{c}\text { Delayed } \\
\text { Change }\end{array}$ & 0.054 & 0.005 & 0.049 & 0.466 & 0.002 & 0.113 \\
\hline $\begin{array}{l}\text { Overall } \\
\text { Change }\end{array}$ & 0.086 & 0.000 & 0.086 & 0.236 & 0.004 & 0.220 \\
\hline \multicolumn{7}{|l|}{$\begin{array}{l}\text { Social } \\
\text { support }\end{array}$} \\
\hline $\begin{array}{r}\text { Initial } \\
\text { Change }\end{array}$ & 0.098 & 0.041 & 0.057 & 0.435 & 0.002 & 0.122 \\
\hline $\begin{array}{l}\text { Delayed } \\
\text { Change }\end{array}$ & -0.017 & -0.005 & -0.012 & 0.879 & $<.001$ & 0.053 \\
\hline $\begin{array}{l}\text { Overall } \\
\text { Change }\end{array}$ & 0.057 & 0.008 & 0.050 & 0.552 & 0.001 & 0.091 \\
\hline \multicolumn{7}{|l|}{$\begin{array}{l}\text { Perceived } \\
\text { behavioral } \\
\text { control }\end{array}$} \\
\hline $\begin{array}{r}\text { Initial } \\
\text { Change }\end{array}$ & 0.008 & 0.026 & -0.018 & 0.798 & $<0.001$ & 0.058 \\
\hline $\begin{array}{l}\text { Delayed } \\
\text { Change }\end{array}$ & 0.038 & -0.009 & 0.046 & 0.450 & 0.002 & 0.117 \\
\hline $\begin{array}{c}\text { Overall } \\
\text { Change }\end{array}$ & 0.026 & -0.012 & 0.038 & 0.569 & 0.001 & 0.088 \\
\hline
\end{tabular}


Table 4: Bivariate and partial correlations between changes in potential mediating psychological constructs and change in self-reported physical activity (females) for self-reported physical activity and nine of 14 potential mediating psychological constructs.

\begin{tabular}{|c|c|c|c|c|c|c|}
\hline & \multicolumn{3}{|c|}{ Bivariate Correlations } & \multicolumn{3}{|c|}{ Partial Correlations } \\
\hline & $\begin{array}{c}\text { Initial } \\
\text { Change PA }\end{array}$ & $\begin{array}{l}\text { Delayed } \\
\text { Change PA }\end{array}$ & $\begin{array}{c}\text { Overall } \\
\text { Change PA }\end{array}$ & $\begin{array}{c}\text { Initial } \\
\text { Change PA }\end{array}$ & $\begin{array}{l}\text { Delayed } \\
\text { Change PA }\end{array}$ & $\begin{array}{c}\text { Overall } \\
\text { Change PA }\end{array}$ \\
\hline \multicolumn{7}{|l|}{ Self-efficacy } \\
\hline Initial Change & .152 & .199 & .227 & .155 & .191 & .220 \\
\hline $\begin{array}{l}\text { Delayed } \\
\text { Change }\end{array}$ & .017 & .157 & .153 & .016 & .166 & .159 \\
\hline $\begin{array}{l}\text { Overall } \\
\text { Change }\end{array}$ & .100 & .261 & .291 & .101 & .261 & .291 \\
\hline \multicolumn{7}{|l|}{ Pros } \\
\hline Initial Change & .130 & .051 & .093 & .133 & .036 & .082 \\
\hline $\begin{array}{l}\text { Delayed } \\
\text { Change }\end{array}$ & -.013 & .120 & .092 & -.012 & .114 & .086 \\
\hline $\begin{array}{l}\text { Overall } \\
\text { Change }\end{array}$ & .044 & .113 & .110 & .047 & .095 & .096 \\
\hline \multicolumn{7}{|l|}{ Cons } \\
\hline Initial Change & -.010 & -.124 & -.104 & -.010 & -.128 & -.107 \\
\hline $\begin{array}{l}\text { Delayed } \\
\text { Change }\end{array}$ & .059 & -.197 & -.127 & .058 & -.198 & -.126 \\
\hline $\begin{array}{l}\text { Overall } \\
\text { Change }\end{array}$ & .069 & -.233 & -.157 & .069 & -.235 & -.157 \\
\hline \multicolumn{7}{|l|}{$\begin{array}{l}\text { Experiential } \\
\text { processes }\end{array}$} \\
\hline Initial Change & .051 & .032 & .061 & .055 & .012 & .046 \\
\hline $\begin{array}{l}\text { Delayed } \\
\text { Change }\end{array}$ & .067 & .165 & .172 & .066 & .176 & .181 \\
\hline $\begin{array}{l}\text { Overall } \\
\text { Change }\end{array}$ & .077 & .164 & .186 & .078 & .161 & .184 \\
\hline \multicolumn{7}{|l|}{$\begin{array}{l}\text { Behavioral } \\
\text { processes }\end{array}$} \\
\hline Initial Change & .327 & .019 & .132 & .327 & .022 & .135 \\
\hline $\begin{array}{l}\text { Delayed } \\
\text { Change }\end{array}$ & -.064 & .373 & .310 & -.062 & .369 & .304 \\
\hline $\begin{array}{l}\text { Overall } \\
\text { Change }\end{array}$ & .140 & .328 & .351 & .141 & .326 & .349 \\
\hline \multicolumn{7}{|l|}{ Severity } \\
\hline Initial Change & .140 & .107 & .145 & .142 & .096 & .137 \\
\hline $\begin{array}{l}\text { Delayed } \\
\text { Change }\end{array}$ & -.001 & .133 & .125 & -.001 & .136 & .127 \\
\hline $\begin{array}{l}\text { Overall } \\
\text { Change }\end{array}$ & .055 & .162 & .173 & .056 & .158 & .170 \\
\hline \multicolumn{7}{|l|}{ Vulnerability } \\
\hline Initial Change & -.064 & .087 & .096 & -.062 & .075 & .087 \\
\hline $\begin{array}{l}\text { Delayed } \\
\text { Change }\end{array}$ & .017 & .038 & .048 & .017 & .038 & .049 \\
\hline
\end{tabular}


Table 4: Bivariate and partial correlations between changes in potential mediating psychological constructs and change in self-reported physical activity (females) for self-reported physical activity and nine of 14 potential mediating psychological constructs. (Continued)

\begin{tabular}{|c|c|c|c|c|c|c|}
\hline $\begin{array}{c}\text { Overall } \\
\text { Change }\end{array}$ & -.015 & .077 & .097 & -.014 & .073 & .094 \\
\hline \multicolumn{7}{|l|}{ Fear } \\
\hline Initial Change & -.041 & .025 & -.019 & -.040 & .019 & -.024 \\
\hline $\begin{array}{l}\text { Delayed } \\
\text { Change }\end{array}$ & .029 & .043 & .054 & .031 & .031 & .045 \\
\hline $\begin{array}{l}\text { Overall } \\
\text { Change }\end{array}$ & -.012 & .047 & .025 & -.010 & .032 & .014 \\
\hline \multicolumn{7}{|l|}{$\begin{array}{l}\text { Response } \\
\text { efficacy }\end{array}$} \\
\hline Initial Change & .094 & .032 & .056 & .097 & .017 & .045 \\
\hline $\begin{array}{c}\text { Delayed } \\
\text { Change }\end{array}$ & .039 & .125 & .112 & .040 & .122 & .109 \\
\hline $\begin{array}{c}\text { Overall } \\
\text { Change }\end{array}$ & .056 & .117 & .109 & .058 & .109 & .102 \\
\hline
\end{tabular}

Bolded values $=p<.05$

ues [16]. This suggests a ceiling/threshold for the possibility of change. Fishbein et al. [7] highlight the importance of demonstrating 'room for change' in psychological constructs as an important step in interventions. There are also other potential methodological artefacts such as measurement times used (too long or too short to capture changes), and attenuation of measurement error. Another explanation for the observed small changes may be explained by response shift theory [36]. Response shift theory refers to a change in one's selfevaluation and/or internal standard (e.g., attitude, perceived control) that result from a change in a measured variable (e.g., PA behavior). An individual for example, may have high perceptions of control before engaging in PA. However, when the individual initiates the behavior, perceptions of control may diminish as barriers to PA and other related constraints may increasingly inhibit the ability to perform PA. Although to date response shift theory has not been evaluated in the social-cognitive domain, this theory may provide one explanation for the observed positive behavioral changes (i.e., PA) while cognitive variables remained relatively stable.

In our study, there was an intervention effect on behavior, despite the intervention's general inability to change the examined psychological mediators. A failure to show mediation by social-cognitive variables despite behavior changes, is common [8,36-39]; indeed most intervention effects on behavior have not been completely accounted for by the proposed mediators [8,34]. Further, a recent study [40] that reviewed mediators of dietary behavior change observed that interventions were relatively unsuccessful in changing mediators. The most powerful and consistent mediator of behavior change interventions in past research has been the behavioral processes of change $[8,34]$, however, this construct was ineffective in the current trial.

Similar measurement (attenuation, response shifts) and method (e.g., time-frame) artefacts as highlighted above may account for this result. Still, the finding is suggestive that our current psychological constructs may be inadequate to account for behavioral changes. This also reflects correlational research where even our best prediction models typically explain less than $30 \%$ of the variance in PA [4]. An expansion of current models to include additional relevant constructs seems prudent yet most of our current theoretical conceptions share considerable redundancy $[7,15,26]$ and thus it is difficult to make suggestions based on the extant literature. Perhaps more sophisticated tests such as an examination of moderators such as personality and environmental characteristics (see Rhodes and Smith [41]) or more specific measurement domains (e.g., belief level vs. aggregation) would be helpful (see Vallance et al. [42]). It is also important to note that the behavior change effect in this study was small ( $2 \%$ variance). While this is typical of worksite interventions [6] and behavioral interventions more generally [5] the precision needed from the purported mediators to account for this very small effect may be difficult. However, it is important that physical activity interventions perform and report mediation analyses even if mediation is not established.

Finally, we must acknowledge the study limitations which include the use of self-report measures to assess physical activity, and the low level of participant retention 
Table 5: Bivariate and partial correlations between changes in potential mediating psychological constructs and change in self-reported physical activity (females) for self-reported physical activity and the remaining five of 14 potential mediating psychological constructs.

\begin{tabular}{|c|c|c|c|c|c|c|}
\hline & \multicolumn{3}{|c|}{ Bivariate Correlations } & \multicolumn{3}{|c|}{ Partial Correlations } \\
\hline & $\begin{array}{c}\text { Initial } \\
\text { Change PA }\end{array}$ & $\begin{array}{l}\text { Delayed } \\
\text { Change PA }\end{array}$ & $\begin{array}{c}\text { Overall } \\
\text { Change PA }\end{array}$ & $\begin{array}{c}\text { Initial } \\
\text { Change PA }\end{array}$ & $\begin{array}{l}\text { Delayed } \\
\text { Change PA }\end{array}$ & $\begin{array}{c}\text { Overall } \\
\text { Change PA }\end{array}$ \\
\hline \multicolumn{7}{|l|}{ Attitude } \\
\hline Initial Change & -.033 & -.130 & -.090 & -.036 & -.113 & -.076 \\
\hline $\begin{array}{c}\text { Delayed } \\
\text { Change }\end{array}$ & -.061 & -.034 & -.065 & -.061 & -.032 & -.063 \\
\hline $\begin{array}{c}\text { Overall } \\
\text { Change }\end{array}$ & -.059 & -.121 & -.123 & -.062 & -.110 & -.115 \\
\hline \multicolumn{7}{|l|}{$\begin{array}{l}\text { Injunctive } \\
\text { norms }\end{array}$} \\
\hline Initial Change & .105 & -.030 & .003 & .104 & -.026 & .006 \\
\hline $\begin{array}{l}\text { Delayed } \\
\text { Change }\end{array}$ & -.102 & .185 & .118 & -.101 & .180 & .113 \\
\hline $\begin{array}{l}\text { Overall } \\
\text { Change }\end{array}$ & -.059 & .166 & .112 & -.058 & .162 & .108 \\
\hline \multicolumn{7}{|l|}{$\begin{array}{l}\text { Descriptive } \\
\text { norms }\end{array}$} \\
\hline Initial Change & .065 & -.011 & -.019 & .066 & -.018 & -.025 \\
\hline $\begin{array}{c}\text { Delayed } \\
\text { Change }\end{array}$ & -.038 & .124 & .068 & -.038 & .120 & .063 \\
\hline $\begin{array}{l}\text { Overall } \\
\text { Change }\end{array}$ & -.020 & .099 & .036 & -.018 & .088 & .027 \\
\hline \multicolumn{7}{|l|}{ Social support } \\
\hline Initial Change & .024 & .054 & .035 & .025 & .050 & .031 \\
\hline $\begin{array}{c}\text { Delayed } \\
\text { Change }\end{array}$ & .236 & .074 & .131 & .237 & .072 & .130 \\
\hline $\begin{array}{l}\text { Overall } \\
\text { Change }\end{array}$ & .209 & .103 & .138 & .211 & .094 & .132 \\
\hline \multicolumn{7}{|l|}{$\begin{array}{l}\text { Perceived } \\
\text { behavior } \\
\text { control }\end{array}$} \\
\hline Initial Change & .157 & .126 & .055 & .157 & .030 & .058 \\
\hline $\begin{array}{l}\text { Delayed } \\
\text { Change }\end{array}$ & .045 & .204 & .188 & .046 & .201 & .185 \\
\hline $\begin{array}{c}\text { Overall } \\
\text { Change }\end{array}$ & .102 & .092 & .102 & .102 & .094 & .104 \\
\hline
\end{tabular}

Bolded values $=p<.05$

throughout the 12 month study period. This should be taken into account in the interpretation of our findings.

In summary, an examination of mediators of PA behavior change using four leading social cognition theories was unable to account for the effect of the intervention on behavior in a worksite intervention. The results highlight the importance of reporting mediation results in randomized controlled trials whether the findings are null or positive. Future studies may wish to focus on more detailed dose-response issues between mediators and behavior, the inclusion of moderators that could affect individual change, or different mediator constructs at higher levels of measurement specificity. Overall, however, the results show a similar pattern to prior research where interventions did not result in a change in mediation of behavior. Continued work on innovative and more powerful intervention approaches to PA is timely. 


\section{Competing interests}

The authors declare that they have no competing interests.

\section{Authors' contributions}

RCP, MAP, KSC and JCS conceived the study. MAP analyzed the data. MAP, RCP, KSC and JCS interpreted the data. MAP, RCP and RER were responsible for drafting the manuscript. All authors critically evaluated the article for content and approved the final version

\section{Acknowledgements}

This study was funded by the Canadian Institutes of Health Research. RCP holds salary awards from the Canadian Institutes of Health Research (Chair in Applied Public Health) and Alberta Heritage Foundation for Medical Research (Health Scholar). KSC is supported by the Canadian Research Chair Program.

\section{Author Details}

1School of Education, University of Newcastle, Callaghan, NSW, Australia, 2 Faculty of Physical Education and Recreation, University of Alberta, Edmonton, AB, Canada, ${ }^{3}$ Alberta Centre for Active Living, University of Alberta, Edmonton, AB, Canada, ${ }^{4}$ Centre for Health Promotion Studies, School of Public Health, University of Alberta, Edmonton, AB, Canada and ${ }^{5}$ Behavioural Medicine Laboratory, School of Exercise Science, University of Victoria, Victoria, BC, Canada

Received: 12 August 2009 Accepted: 3 May 2010

Published: 3 May 2010

\section{References}

1. U.S. Department of Health and Human Services: Physical activity and health: A report of the Surgeon General. Atlanta, GA: U.S. Department of Health and Human Services; 1996.

2. Cameron C, Wolfe R, Craig CL: Physical activity and sport: Encouraging children to be active. Ottawa, ON: Canadian Fitness and Lifestyle Research Institute: 2007

3. Bauman A, Sallis JF, Dzewalktowski DA, Owen N: Toward a better understanding of the influences of physical activity. The role of determinants, correlates, causal variables, mediators, moderators, and confounders. Am J Prev Med 2002, 23:5-14

4. Baranowski T, Anderson C, Carmack C: Mediating variable framework in physical activity interventions. How are we doing? How might we do better? Am J Prev Med 1998, 15:266-297.

5. Hillsdon M, Foster C, Thorogood M: Interventions for promoting physical activity. Cochrane Database Syst Rev 2005, 1:CD003180

6. Dishman RK, Oldenburg B, O'Neil H, Shepard RJ: Worksite physical activity interventions. Am J Prev Med 1998, 15:344-359.

7. Fishbein M, von Haeften I, Appleyard J: The role of theory in developing effective interventions: Implications from Project Safer. Psychol Health Med 2001, 6:223-238.

8. Lewis BA, Marcus BH, Pate RR, Dunn AL: Psychosocial mediators of physical activity behavior among adults and children. Am J Prev Med 2002, 23:26-35.

9. Bauman A, Pratt M, Sallis JF: Environment and policy interventions to promote physical activity. Am J Prev Med 1998, 15:379-395.

10. Spence J, Lee R: Toward a comprehensive model of physical activity. Psychol Sport Exerc 2003, 4:7-24.

11. Sallis JF, Owen N: Ecological models. In Health Behavior and Health Education Edited by: Glanz K, Lewis MF, Rimer BK. California: Jossey-Bass; 2002:403-424

12. Vallance J, Courneya K, Plotnikoff R, Mackey J: Randomized controlled trial of the effects of print materials and step pedometers on physical activity and quality of life in breast cancer survivors. J Clin Oncol 2007 25(17):2352-2359.

13. Weinstein ND:Misleading tests of health behaviour theories. Ann Behav Med 2007, 33(1):1-10.

14. Sheeran P: Intention-behavior relations: A conceptual and empirical review. In European Review of Social Psychology Volume 12. Edited by: Stroebe W, Hewstone M. Chichester: John Wiley \& Sons; 2002:1-36.

15. Noar SM, Zimmerman RS: Health behavior theory and cumulative knowledge regarding health behaviors: Are we moving in the right direction? Health Educ Res 2005, 20(3):275-290.
16. Plotnikoff RC, Brunet S, Courneya KS, Spence J, Birkett NJ, Bess M, Whiteley $\mathrm{J}$ : The efficacy of stage-matched and standard public health materials for promoting physical activity in the workplace: The Physical Activity Workplace Study (PAWS). Am J Health Promot 2007, 21 (6):501-509.

17. Prochaska J, Valicer W: The transtheoretical model of health behavior change. Am J Health Promot 1997, 12(1):38-48,

18. Ajzen I: The theory of planned behavior. Organ Behav Hum Decis Process 1991, 50:179-211.

19. Rogers R: Cognitive and psychological processes in fear appeals and attitude change: A revised theory of protection motivation. In Social Psychology: A Sourcebook Edited by: Cacioppo JT, Petty RE. New York: Guilford Press; 1983:153-176.

20. Bandura A: Health promotion by social cognitive means. Health Educ Behav 2004, 31(2):143-64

21. Rhodes R, Plotnikoff R, Courneya K: Predicting the physical activity intention-behaviour profiles of adopters and maintainers using three social cognition models. Ann Behav Med 2008, 36:244-252.

22. Public Health Agency of Canada: Canada's Physical Activity Guide to Healthy Living. [http://phac-aspc.gc.ca/pau-uap/fitness/pdf/ guideEng.pdf.

23. Cohen J: Statistical power analysis for the behavioral sciences Hillsdale: Erlbaum; 1988.

24. Godin G, Shepard RJ: A simple method to assess exercise behavior in the community. Can J Public Health 1985, 77:359-361.

25. Brown WJ, Bauman AE: Comparison of estimates of population levels of physical activity using two measures. Aust NZ J Public Health 2000, 24(5):520-525

26. Bandura A: Social foundations of thought and action: a social cognitive theory Englewood Cliffs: Prentice Hall; 1986.

27. MacKinnon DP, Lockwood CM, Hoffman JM, West SG, Sheets V: A comparison of methods to test mediation and other intervening variable effects. Psychological Methods 2002, 7(1):83-104.

28. Baron RM, Kenny DA: The moderator-mediator variable distinction in social psychological research: Conceptual, strategic and statistical considerations. J Pers Soc Psychol 1986, 51:1173-1182.

29. MacKinnon DP, Fairchild AJ, Fritz MS: Mediation analysis. Annu Rev Psychol 2007, 58(1):593-614

30. Sobel ME: Asymptotic intervals for indirect effects in structura equations models. In Sociological methodology Edited by: Leinhart S. San Francisco: Jossey-Bass; 1982:290-312

31. MacKinnon DP, Warsi G, Dwyer JH: A simulation study of mediated effect measures. Multivariate Behav Res 1995, 30:41-62.

32. Fritz MS, MacKinnon DP: Required sample size to detect the mediated effect. Psychological Science 2007, 18(3):233-239.

33. Lubans DR, Foster C, Biddle SJH: A review of mediators of behavior in interventions to promote physical activity among children and adolescents. Prev Med 2008, 47:463-470.

34. Rhodes RE, Pfaeffli LA: Mediators of physical activity behaviour change among adult non-clinical populations: A review update. International Journal of Behavioral Nutrition and Physical Activity in press.

35. Opdenacker J, De Bourdeaudhuij I, Auweele Y Vanden, Boen F: Psychosocial mediators of a lifestyle physical activity intervention in women. Psychology of Sport \& Exercise 2009, 10(6):595-601.

36. Sprangers MAG, Schwartz CE: Integrating response shift into healthrelated quality of life research: a theoretical model. Soc SciMed 1999, 48:1507-1515

37. Dallow CB, Anderson J: Using self-efficacy and a transtheoretical model to develop a physical activity intervention for obese women. Am J Health Promot 2003, 17:373-381.

38. Fahrenwald NL, Atwood JR, Johnson DR: Mediator analysis of moms on the move. West J Nurs Res 2005, 27:271-291.

39. Napolitano MA, Papandonatos GD, Lewis BA, Whiteley JA, Williams DM, King AC, Bock BC, Pinto B, Marcus BH: Mediators of physical activity behaviour change: A multivariate approach. Health Psychol 2008, 27(4):409-418

40. Cerin E, Barnett A, Baranowski T: Testing theories of dietary behavior change in youth using the mediating variable model with intervention programs. Journal of Nutrition Education \& Behavior 2009, 41:309-318

41. Rhodes RE, Smith NEl: Personality correlates of physical activity: A review and meta-analysis. Br J Sports Med 2006, 40:958-965. 
42. Vallance J, Courneya K, Plotnikoff R, Mackey J: Analyzing theoretical mechanisms of physical activity behaviour change in breast cancer survivors: Results from the activity promotion (ACTION) trial. Ann Behav Med 2008, 35(2):150-158.

43. Plotnikoff R, Blanchard C, Hotz S, Rhodes R: Validation of the decisional balance constructs of the transtheoretical model in the exercise domain: A longitudinal test in a population sample. Measurement in Physical Education and Exercise Science 2001, 5(4):191-206.

44. Plotnikoff R, Hotz S, Birkett N, Courneya K: Exercise and the transtheoretical model: A longitudinal test of a population sample. Prev Med 2001, 33:441-452.

45. Plotnikoff R, Rhodes R, Trinh L: Protection Motivation Theory and Physical Activity: A longitudinal test among representative population sample of Canadian adults. J Health Psychol 2009, 14(8):1119-34.

46. Plotnikoff RC, Higginbotham N: Protection Motivation Theory and exercise behaviour change for the prevention of coronary heart disease in a high risk, Australian representative community sample of adults. Psychol Health Med 2002, 7(1):87-98.

47. Courneya K, Plotnikoff R, Hotz S, Birkett N: Predicting exercise stage transitions over two consecutive 6-month periods: A test of the theory of planned behaviour in a population-based sample. Br J Health Psychol 2001, 6:135-150.

48. Courneya K, Plotnikoff R, Hotz S, Birkett N: Social support and the theory of planned behavior in the exercise domain. Am J Health Behav 2000, 24(4):300-308.

doi: $10.1186 / 1479-5868-7-32$

Cite this article as: Plotnikoff et al., A test of cognitive mediation in a 12month physical activity workplace intervention: does it explain behaviour change in women? International Journal of Behavioral Nutrition and Physical Activity 2010, 7:32

Submit your next manuscript to BioMed Central and take full advantage of:

- Convenient online submission

- Thorough peer review

- No space constraints or color figure charges

- Immediate publication on acceptance

- Inclusion in PubMed, CAS, Scopus and Google Scholar

- Research which is freely available for redistribution

Submit your manuscript at www.biomedcentral.com/submit
C) BioMed Central 